\title{
Preschool Teachers' Experiences in Working with Children in an Inclusive Educational Facility
}

\author{
Jasna Kudek Mirošević ${ }^{1}$ Daria Tot $^{2}$, Renata Šamo ${ }^{3}$ \\ ${ }^{1}$ Faculty of Teacher Education, University of Zagreb, Croatia \\ ${ }^{2}$ Faculty of Teacher Education, University of Zagreb, Croatia \\ ${ }^{3}$ Faculty of Teacher Education, University of Zagreb, Croatia
}

\begin{abstract}
Inclusion is a process that signifies an equal approach to quality education for all children and supports their development and learning. Recognizing the role of a leader, mediator and rolemodel, among others, is particularly relevant for the contemporary preschool teacher. The preschool teacher does represent a role-model for children's behavior and enables them through everyday experiences - to learn how to respect and appreciate differences, as well as to develop their participation skills. It is important to create an environment in which every child will grow and develop, feel as an equal society member, with equal rights and values, in which differences are a source of fortune and learning opportunities. In a child upbringing, cooperation with parents and experts is important. Continuous professional development and lifelong learning is a preschool teacher's prerequisite for realizing an inclusion philosophy in education. Having in mind the $21^{\text {st }}$ century preschool teacher, this paper is aimed at indicating the need for strengthening his/her professional competences in inclusive work with preschool children. The aim of this research is to determine how much preschool teachers individualize processes in activities planned for the children with disabilities, and whether they consider themselves competent to conduct such activities to satisfy the principles of an inclusive environment, all in accordance with legislation in the Croatian education system. The sample includes preschool teachers $(\mathrm{N}=132)$ in educational facilities across the Republic of Croatia. The results should reveal the level of individualized educational practice, with a special emphasis on dilemmas and challenges arising from them (research results).
\end{abstract}

Keywords: children with disabilities, cooperation, diversity, preschool teachers' professional development, individualized approach

\footnotetext{
${ }^{1}$ Faculty of Teacher Education, University of Zagreb, Croatia

${ }^{2}$ Faculty of Teacher Education, University of Zagreb, Croatia

${ }^{3}$ Faculty of Teacher Education, University of Zagreb, Croatia
} 


\section{LENAEDULATIIN \\ 27-29 March, 2020 \\ Oxford, United Kingdom}

\section{Introduction}

Inclusion of children with disabilities into regular educational groups has developed significantly in the past two decades. During that time, neither theoreticians nor practitioners have reached the consensus on the meaning of the term 'inclusion,' and over the years, it has changed (Odom and Diamond, 1998). According to Lorenzo (2002), the different uses of the given term and its different descriptions may lead to confusion. Although there is no generally accepted definition, it could be said that it is a process in which children with disabilities regardless of the degree and the type of disability - are raised and educated in an environment with their peers. Inclusion signifies the whole community's care for children, simultaneously affirming tolerance and the child's right to be different as a co-constructor of his or her own identity and culture (Sekulić-Majurec, 1997; Torstenson-Ed, 2007). It is a reflection of society's democracy in regard to enabling independence, acceptance and respect towards difference and true inclusion, not just in planning joint work with all children. The aim is to prepare children to be independent, nurture critical thinking and respect individuality.

Inclusion means believing in the development of individual needs of every single child. At the same time, it is directed at satisfying the needs of certain family members who, full of trust, have enrolled the child into a preschool facility. Being the first and primary child educator, the family's influence is great, which is why they should be seen as partners whose role in the education process is important. By connecting and cooperating with the children's families, a foundation for parents' education and a chance for providing direct support in the involvement in the upbringing of their children is created.

Inclusion in the early years can be summarized as (Devarakonda, 2013): enabling diversity, removing barriers, giving equal opportunities, showing respect, celebrating differences, meeting needs, ensuring ongoing processes, overcoming exclusion, providing better access, and increasing participation. It should be noted, as Devarkonda (2013) emphasizes, that every child is specific in his or her own way, so inclusion can have a different meaning to each of them. Children surely have the right to the maximal possible development, especially in the period of early childhood, with the family's systematic and quality involvement (UN, 2006; 2015). Based on the above-mentioned, it could be claimed that quality inclusive upbringing is distinguished by the following characteristics:

1. It allows the preschool teacher to meet needs of every child.

2. In meeting children's needs, a partnership and quality cooperation among parents, preschool teachers and a professional team are present.

3. Program implementation is based on research, and programs are aligned with the culture, language and child's developmental needs.

4. Children are focused on each other and they play together all the time during which they are in an inclusive facility.

5. It is directed at the child's entire, holistic personality.

6. It establishes a permanent quality relationship with the family, the partners and the local community. 
Establishing social interaction and a relationship among peers is considered to be the core value of inclusion (Odom, 2002), and the purpose of a successful inclusion is the development of constructive relationships among children (Heekin and Mengel, 1997). By mutual learning, at the same time, children are enabled to be individually successful. In order to achieve this, it is necessary to create an appropriate environment, in which diversity is a source of fortune and a learning opportunity for every child. Although research has shown (e.g. Odom, 2000) that the quality of preschool inclusive environments is not insignificant and that, at the very least, it can be comparable with the quality of traditional special education and the one intended exclusively for regular children, the quality of preschool environment in general is average. This leads to different questions about the quality of inclusive programs (Bailey et al., 1998; Odom, 2000). All the while, the basic principles of inclusive environment in a developmentally appropriate and child-centered approach should be continuously questioned, primarily through an individualized and holistic approach to child development. It is about the use of inclusive upbringing on more levels: in interaction of preschool teachers with children and their families, as well as with co-experts in an education facility and within the more immediate or wider surroundings. A quality relationship and good cooperation with the professional team members, including a pedagogue, a psychologist, experts in the field of education and rehabilitation science and others, are of the utmost importance. With the knowledge and use of effective communication skills by all of the participants, it is possible to create the prerequisites for building and continuous development of cooperation between preschool teachers and professional associates in a preschool facility. The course and result of cooperation will often depend on various professional knowledge and skills, as well as on attitudes of each participant. This is especially important when working with children and their parents (for example, when introducing challenges with which a parent of a child with disabilities may face), but also in a mutual cooperation between preschool teachers and professional associates. This is the reason why in a quality education facility everyone participates in finding various solutions which ultimately target the well-being of children in the group. At the same time, adults stand out as role-models in every child's upbringing, responsible and self-regulated participants with an initiative, a sense of individuality and (different) identities in a cooperatively oriented community. This makes the preschool teacher's responsibilities in the implementation of quality upbringing practice even greater, so that more complex and various competences are needed.

Inclusive upbringing presupposes competent preschool teachers who take every child's individual needs into consideration. They help children in understanding, accepting and respecting differences. Besides, they respect and develop a quality of acceptance with regard to respecting the child's values, regardless of his or her origin, looks, behavior or abilities. A child-centered, individualized approach leads to meaningful changes in recognizing the preschool teacher as an inclusive educator - compassionate and authentic. Expecting a high level of competence is important for a child's further guidance and creation of conditions for learning (Rinaldi, 2006; Tot, 2013). In a curriculum designed this way, an individualized approach supports the educational paradigm based on the child's interests and needs, with no focus on a certain disability. It represents one of the basic principles and values needed for the implementation of inclusive educational practice (Okvir za poticanje i prilagodbu iskustava 
učenja te vrednovanje postignuća djece i učenika s teškoćama $\left.{ }^{4}, 2016\right)$ since a diversity in abilities and needs is natural and desirable in every society. Through an individualized approach, preschool teachers influence the child's development by setting goals adjusted for him or her. Because of that, not only do they possess the knowledge of the principles of child development, but they also possess the knowledge to design the curriculum and think about every child in the group, therefore, creating and developing his or her emotional safety (Mikas and Roudi, 2012). The answer to children's diversity in groups is found in a developmentally appropriate practice and a curriculum directed towards different strategies and activities, alongside planning and providing appropriate activities. Through individualization, the preschool teacher allows the child a possibility to choose a certain activity in which he or she will advance at his or her own pace and work in accordance with his or her own interests. At the same time, the whole group is dynamic and astatic given the fact that children change the surrounding according to their own interests and needs. Moreover, by employing individualized procedures, the preschool teacher influences the child's engagement in linguistic, social and cognitive competences aimed at acquiring academic skills and future school achievements (Michelle, 2012).

A quality and successful upbringing in an inclusive education facility is the one which ensures every child some possibilities for authentic and creative expression, contentment and relaxation with a complete sense of acceptance from all participants. In order to do that, the preschool teacher also needs to release his own creativity and simultaneously adjust his or her educational procedures, using strategies which encourage children's socially and individually desirable personality traits. The preschool teacher has to be adequately qualified to be able to react in an appropriate way when he or she is expected to do so. He or she questions his or her attitudes towards inclusion and becomes ready to continuously work on his/her professional development. This way, he or she also benefits from the entire process and can positively influence possible individuals' negative attitudes towards inclusion. Research worldwide, just as in Croatia, has mostly shown that preschool teachers think that children with disabilities should be educated in regular schools later on during their primary education since they believe these children will benefit from inclusion (Avramidis et al., 2000; Crane-Mitchell and Hedge, 2007). However, they also believe that they do not have enough knowledge about the direct practice and activities for inclusion of such children, i.e. they do not possess enough competences to work with children with various disabilities. Their belief is, therefore, that in comparison to primary school teachers - they are more motivated to attend some additional training on the strategies required for working with children with disabilities (Kudek Mirošević and Jurčević Lozančić, 2014).

\subsection{Problem and objective}

The preschool teachers of early and preschool-age children are primarily responsible for caring about the children in their group and caring about them, as well as for planning activities and their assessment. Alongside experience, attitudes and knowledge are the key

\footnotetext{
${ }^{4} \mathrm{~A}$ framework for encouraging and adapting learning experiences and evaluating the achievements of children and students with disabilities.
} 
indicators of a quality inclusive preschool practice. As reflexive practitioners they are familiar with inclusive principles, have experience in working with children with disabilities, and try to meet various educational needs of all children in their groups (Crane-Mitchell and Hedge, 2007; cited in Akalin et al.). A successful inclusion is closely related to the ability of adjusting surroundings and methods to children's educational needs, by using efficient methods and strategies for teaching appropriate behavior and ensuring equal learning opportunities for evry child (Bricker, 1995). Taking this into consideration, a step back should be taken from the traditional understanding of preschool teachers' competences, defined regarding knowledge, skills and attitudes. To encompass different aspects which characterize some quality educational work, a shift in understanding must be made: from the technical conceptualization of educational work (Do I do things right?) to an intrinsically reflective nature (Do I do the right things?) (Vandenbroeck et al., 2010).

Based on the previously stated, the aim of the current research is to determine to what extent preschool teachers individualize processes in the activities planned for children with disabilities, and whether they consider themselves competent to conduct such activities in order to satisfy the principles of an inclusive environment, all in accordance with the legislation relevant for the Croatian education system. Moreover, this research aims to examine how much preschool teachers participate in a team work and a cooperation with professional associates in a preschool facility on the one side, and with the parents of children with disabilities on the other side.

\section{Methods}

\subsection{The sample of respondents}

There were 132 preschool teachers employed in preschool education institutions in the Republic of Croatia, who had participated in the survey, of which $99.1 \%$ were women and $0.9 \%$ were men. Regardless of the fact that the sample includes preschool teachers from all over the country, in accordance with the legislation and Zakon o ranom predškolskom odgoju $i$ obrazovanju ${ }^{5}$, preschool teachers provide educational support related to educational inclusion and the child rights to be included in the education system which is the most appropriate and closest to their place of residence (Narodne novine ${ }^{6}, 94 / 13$ ). The years of their work experience as preschool teachers are shown in Table 1.

Table 1: Respondents by years of work experience (WE) (\%) $(N=132)$

\begin{tabular}{|c|c|c|c|c|c|c|}
\hline $\begin{array}{c}\text { less than 5 } \\
\text { years of } \\
\text { WE }\end{array}$ & $\begin{array}{c}6-10 \text { years } \\
\text { of WE }\end{array}$ & $\begin{array}{c}11-15 \text { years } \\
\text { of WE }\end{array}$ & $\begin{array}{c}16-20 \text { years } \\
\text { of WE }\end{array}$ & $\begin{array}{c}21-25 \text { years } \\
\text { of WE }\end{array}$ & $\begin{array}{c}26-30 \text { years } \\
\text { of WE }\end{array}$ & $\begin{array}{c}\text { over } 30 \\
\text { years of } \\
\text { WE }\end{array}$ \\
\hline $32.5 \%$ & $27.8 \%$ & $16.1 \%$ & $6.2 \%$ & $5.5 \%$ & $4.4 \%$ & $7.5 \%$ \\
\hline
\end{tabular}

\footnotetext{
${ }^{5}$ Law on Early Preschool Education.

${ }^{6}$ Official Gazette.
} 


\section{LINAEDULATION \\ 27-29 March, 2020 \\ Oxford, United Kingdom}

\subsection{Measuring instrument and data processing methods}

The survey was conducted in 2019 with a questionnaire for preschool teachers specifically constructed for the given purposes. The questionnaire consisted of three parts. In the first one, the introductory section with general instructions on filling in, the respondents were asked to answer all the questions honestly and to fill in the questionnaire completely, since it was used exclusively for the research into a preschool inclusive practice. The ethical aspects of the examination were respected, given that all the respondents were informed of the purpose and aim of this research. The ethical principles of voluntariness, anonymity and confidentiality of information were also respected, as well as the possibility of waiving or not responding to an assertion.

The second part of the questionnaire concerned the sociodemographic characteristics of the respondents (sex and years of work experience as a preschool teacher). Having in mind the purposes of the current paper, 11 statements were taken from the third part of the questionnaire, for which the preschool teachers were instructed to choose on a four-level Likert scale how much they agree with the given statements $(1-$ strongly disagree, 2 partially agree, 3 - agree, 4 - strongly agree). They were also asked to report on the frequency of individualized procedures they use with children with disabilities within planned activities ( 1 - never, 2 - once a year, 3 - once a month, 4 - every week, 5 - every day).

The statements considered their self-assessment of experience in educational work in a preschool facility related to establishing a quality inclusion and creating an inclusive environment for children with disabilities, as well as specific competences for working with children with disabilities. It should be added that the above-mentioned items are based on the European Policy Cooperation (ET 2020 framework) - The strategic framework for European cooperation in education and training. The main approach behind the strategic framework is lifelong learning and the outcomes on all levels of education (preschool education included); it covers learning in all contexts, such as formal, non-formal and informal. The Council's recommendation proposal relates to quality early and preschool education, which can thus be a good basis for a child's later success in life, e.g. it can increase his/her opportunities for education, employment and social integration. The special emphasis is put on the children raised in disadvantaged environments, as well as on the definition of an appropriate individual curriculum for each child who needs it, along with the competences and conditions of the staff in charge of early and preschool education. With this in mind, the importance of high quality early and preschool education is beyond question, being constantly subject to the evaluation and development of preschool teachers' competences.

The process of the current paper quantitative analysis includes the interpretation and argumentation of the grouped statements from the questionnaire. Using the quantitative analysis of the questionnaires administered to the preschool teachers, the statements were grouped as follows: the first group (Table 2) refers to the preschool teachers' self-assessment of the experience and competences, the role in a cooperation with parents and professional associates, as well as the recognition of a quality social inclusion of children with disabilities among peers; whereas the second group (Table 3) regards the self-assessment of the frequency of individualized procedures and planned activities used by the preschool teachers, along with their interaction with children with disabilities. 
Starting from the statements grouped as described above for the purpose of determining the preschool teachers' individualized approach to children with disabilities, self-assessment of experience and competences for a quality cooperation with parents and professional associates, the frequency of data distribution was used, the data were calculated as percentages and presented in a table.

\section{Results and Discussion}

Considering the applied quantitative methodology by frequency analysis, Table 2 shows the frequency distribution of the results according to the respondents' level of agreement on their experience and competence, role in cooperation with parents and professional associates, and recognition of a quality social inclusion of children with disabilities among peers.

Table 2: Frequency distribution of the results - experiences and competences of preschool teachers, their role in cooperation with parents and professional associates, recognition of quality social inclusion of children with disabilities (\%)

\begin{tabular}{|l|c|c|c|c|}
\hline \multicolumn{1}{|c|}{ Statement } & $\begin{array}{c}\text { Strongly } \\
\text { disagree } \\
\%\end{array}$ & $\begin{array}{c}\text { Partially } \\
\text { agree } \\
\%\end{array}$ & $\begin{array}{c}\text { Agree } \\
\%\end{array}$ & $\begin{array}{c}\text { Strongly } \\
\text { agree } \\
\%\end{array}$ \\
\hline $\begin{array}{l}\text { I believe that preschool teachers should be } \\
\text { professionally educated in the field of inclusion. }\end{array}$ & 1.6 & 12.4 & 40.3 & 45.7 \\
\hline $\begin{array}{l}\text { I consider myself competent to carry out individual } \\
\text { activities with children with disabilities. }\end{array}$ & 40.3 & 17.9 & 17.8 & 24.0 \\
\hline $\begin{array}{l}\text { I recognize characteristics and peculiarities of } \\
\text { certain disabilities in a child. }\end{array}$ & 3.3 & 17.9 & 17.9 & 60.9 \\
\hline $\begin{array}{l}\text { Professional associates in my kindergarten also } \\
\text { participate in direct work with children with } \\
\text { disabilities. }\end{array}$ & 12.4 & 58.9 & 22.5 & 6.2 \\
\hline $\begin{array}{l}\text { The preschool teacher is obliged to inform the } \\
\text { parents of a child about the observed peculiarities } \\
\text { and disabilities. }\end{array}$ & 6.2 & 24.0 & 31.0 & 38.8 \\
\hline $\begin{array}{l}\text { The preschool teacher is obliged to inform the } \\
\text { professional associates about the peculiarities and } \\
\text { disabilities observed in a child. }\end{array}$ & 0 & 2.3 & 27.9 & 69.8 \\
\hline $\begin{array}{l}\text { The children with disabilities need the help of } \\
\text { professional associates. }\end{array}$ & 0 & 0.8 & 19.4 & 79.8 \\
\hline $\begin{array}{l}\text { The children with disabilities have difficulties in a } \\
\text { social interaction. }\end{array}$ & 2.2 & 54.3 & 32.6 & 10.9 \\
\hline
\end{tabular}

Given the dependence of the quality of early and preschool education system on the competences (integration of knowledge, skills, attitudes, motivation) of professionals working with children and their families (Urban et al., 2012), the current research results show that the preschool teachers mostly considered themselves competent when it comes to recognizing characteristics and peculiarities of certain disabilities in children (60.9\%). However, $40.3 \%$ of 


\section{LINAEDULATION \\ 27-29 March, 2020 \\ Oxford, United Kingdom}

them believe that they are not competent to carry out individual activities with children with disabilities. Buysse and associates (1999) state that the quality of inclusive programs varies depending on the program philosophy, administrative support, professional development and preschool teachers' attitudes. Since the work of preschool education teachers requires not only a high level of theoretical knowledge, but also knowledge about methodology skills, their key competences should include diverse skills, commitment and sensibility with regard to working with children having different psychophysical abilities and capacities. Accordingly, a high motivation of preschool teachers for lifelong learning is needed; the results indicate that more than $85 \%$ of the preschool teachers are motivated for their professional development in the field of educational inclusion. About $70 \%$ of them believe that professional associates (traditionally, in the Croatian education system, these are pedagogues, psychologists and experts in educational and rehabilitation science - educational rehabilitators, speech therapists and social pedagogues) are insufficiently involved in a direct work with children with disabilities. This shows that a better connection and cooperation between preschool teachers and professional associates in preschool institutions is needed, which is already a key aspect of work, especially when it comes to the children with special educational needs. Specifically, a strong collaboration with professional associates and parents is crucial, as they learn about cultural knowledge and acquire communication skills. This has been revealed by research which emphasizes that preschool teachers need some ongoing support from specialized professionals in educating them on the use of new methods and materials for working in inclusive settings (Eiserman et al., 1995; Coombs-Richardson and Mead, 2001). The results further show that about $70 \%$ completely feel that they are not obliged to inform their professional associates of the peculiarities and disabilities observed in a child. This points out the need for professional associates, given the specific competences they have, to be more present in educational groups and, while observing the activities conducted by preschool teachers, to identify the educational support a particular child needs in order to work cooperatively and in a team with preschool teachers; they are additionally expected to agree on and propose the planning and using of strategies that will allow all children to develop their own abilities. The obtained findings clearly indicate that the preschool teachers have little experience with individualized methods when they perceive certain disabilities in a child. Therefore, more than $45 \%$ of them think that they need professional education in the field of inclusion. Some of them $(54.3 \%)$ claim that the children with disabilities have difficulties in a social interaction, which points out a need to create a supportive environment and optimal conditions for the holistic development of each child's personality. However, about $70 \%$ of them also think that the preschool teacher is obliged to inform a child's parents about the observed peculiarities and disabilities, which indicates that they do recognize such peculiarities and disabilities. This implies a need to provide an individualized support in accordance with every child's educational needs and developmental potentials, for which the parental involvement should be ensured.

The fact arises from the results that every preschool teacher, as a practitioner, needs constant training and acquisition of additional competences, which is a continuous process that covers a need for individual development at the level of professional knowledge, practice and values. Although it is important to have a set of knowledge and practical experiences, practitioners (preschool teachers) and teams (professional associates) need to develop reflexive competences since they work in a very complex, unpredictable and diverse context 
with the children with different abilities and opportunities. The 'competence system' asks for a collaboration between preschool teachers and professional associates, just as all the professionals in a preschool facility are required to engage in the shared learning and critical reflection (Urban et al., 2012). What is mentioned above leads to a conclusion that the results can be viewed in the context of similar case studies (Urban et al., 2012), where the authors point out the importance of building reciprocal relationships with parents in the context of diversity. The research shows, however, that many profiles of experts with the formally acquired professional competences, as well as their subsequent professional development, are mainly focused on the knowledge and competences needed for working with children in general, neglecting the importance of working and collaborating with parents, children with disabilities, and local communities. In this sense, a successful educational inclusion is closely linked to the knowledge and ability of preschool teachers to adjust the environment and methods to children's educational needs, using efficient methods and strategies for teaching children appropriate behavior, acquiring new knowledge and experiences, that is, providing the equal learning opportunities for all children (Bricker, 1995 cited in Akalin et al., 2014).

The frequency analysis of the results in Table 3 relates to the frequency of conducting individualized procedures with the children with disabilities within preschool teachers' planned activities.

Table 3: Frequency distribution of the results - frequency of conducting individualized procedures with children with disabilities within planned activities (\%)

\begin{tabular}{|l|c|c|c|c|c|}
\hline \multicolumn{1}{|c|}{ Statements } & Never & $\begin{array}{c}\text { Once a } \\
\text { year }\end{array}$ & $\begin{array}{c}\text { Once a } \\
\text { month }\end{array}$ & $\begin{array}{c}\text { Every } \\
\text { week }\end{array}$ & $\begin{array}{c}\text { Every } \\
\text { day }\end{array}$ \\
\hline $\begin{array}{l}\text { I conduct individualized procedures and exercises } \\
\text { with children with disabilities. }\end{array}$ & 0 & 0 & 23.8 & 35.7 & 40.5 \\
\hline $\begin{array}{l}\text { I conduct workshops to engage and connect children } \\
\text { with disabilities with their peers without disabilities. }\end{array}$ & 37.6 & 23.2 & 18.4 & 4.0 & 16.8 \\
\hline $\begin{array}{l}\text { Children with disabilities are involved in interacting } \\
\text { with me. }\end{array}$ & 0 & 0.5 & 11.4 & 76.5 & 11.6 \\
\hline
\end{tabular}

Given that an individualized approach is understood as the concept that every child can learn if approached individually, preschool teachers can be successful if they use efficient support strategies when conducting activities. The obtained findings show that the preschool teachers of the children with disabilities regularly perform individualized procedures and exercises, i.e. most of them do it daily (40.5\%) and weekly (35.7\%). When it comes to conducting workshops in order to engage and connect the children with disabilities with their peers without disabilities, the results show that most of them (37.6\%) never conduct them. Specifically, the results suggest that one of their basic needs is learning how to conduct workshops in accordance with the requirements of educational inclusion and how to include the children with disabilities in the daily routine (Hadadian and Hargrove, 2001). Therefore, in line with the results presented in Table 2, it can be concluded that the preschool teachers need further training in creating and implementing diverse work methods in order to gain more knowledge, skills and experience in their workplace, i.e. in their educational group. (Crane-Mitchell and Hedge, 2007). 
A safe, responsive and nurturing environment is an important part of supporting the learning and development of early childhood and preschool age children. Such an environment also helps them to prevent behaviors that lead to children developing social integration difficulties and serves as a prevention and fundamental component of intervention in children with identified behavioral problems (Division for Early Childhood Recommended Practices DEC-RP, 2014). Therefore, an important aspect of relationships outside the family and parent ones, with implications for children to adapt to the environment, is precisely the relationship and interaction between the preschool teacher and the child. Consequently, researchers have started focusing on the early identification of individual differences in the self-assessment of preschool children (Colwell and Lindsey, 2003). The same authors emphasize that a greater connection in the relationship between the preschool teacher and the child affects the child's perception of peers. The quality of this preschool teacher-child relationship may be a determinant of a child's social functioning in the educational group. In other words, a positive interaction between the preschool teacher and the child can generally promote a more positive attitude towards the involvement in a preschool facility and transfer into a positive relationship with peers. Also, in accordance with the importance of mutual interactions, the children who have a safe relationship with an adult in a preschool setting may be more autonomous to get engaged with peers, and the consequences may in particular have a greater impact on children's self-perception than on their perception of peers (Colwell and Lindsey, 2003). Having this in mind, an interaction between the preschool teacher and each child, and especially a child with social integration difficulties, is important. The results presented in this paper show that the majority of preschool teachers, $76.5 \%$, weekly ensure that the children with disabilities are involved in an interaction with them, which is significant, given the individual planning that should be focused on each child and the practices presupposing an environment which encourages the child's social integration, and relates to the aspects of space, materials and equipment, routine and activities. For preschool teachers to support the learning of every child through all developmental areas, the type of personal interaction with each of them is important for improving the social integration of the children with disabilities among peers; it is also crucial for ensuring their further educational opportunities. Unfortunately, many experts are not sure how to, by interacting with a single child, create an environment that supports the learning of all children in a group, given each child's particular features and required developmental areas (e.g. social, communicative, cognitive, motor). Specifically, the results show that only $11.6 \%$ of the preschool teachers participate, on a daily basis, in activities with children through interactions with each other, and $11.4 \%$ of them do it only once a month.

\section{Conclusion}

Preschool teachers are a key to considerations about inclusive education in a preschool facility and its implementation. Such an important role requires the possession of various professional (general and specific) competences, as well as their constant questioning, selfreflection and self-evaluation. In addition to the knowledge and skills acquired during the primary higher education, a quality inclusive preschool teacher is constantly working on education, professional improvement and lifelong learning. The pedagogical inclusion he or she practices on a daily basis refers to creating an environment that will provide every child 


\section{LENAEDULATIIN \\ 27-29 March, 2020 \\ Oxford, United Kingdom}

with the necessary sense of security, support and holistic development. Therefore, he or she uses an individualized approach and is in a constant interaction with children and their families, also with their co-experts - a team of professional associates. Their day-to-day experiences are an indicator of successful implementation that leads to the mutual contentment of all participants, and thus the quality and further development in working with children in inclusive preschool facilities. This research seeks to highlight the importance of these segments by examining preschool teachers' views on their competence in planning and implementing individualized procedures, and in collaborating and establishing teamwork with professional associates and parents of the children with disabilities. The obtained results show that preschool teachers vastly consider themselves competent when it comes to recognizing the characteristics and peculiarities of certain disabilities in children, but not when it comes to carrying out individual activities with these children. They also mostly feel that they are not obliged to inform their professional associates about the characteristics and difficulties observed in a child. Urban et al. (2012) consider that "competence" in the context of early childhood care and education should be understood as a characteristic of the whole system. Given the results of this research, according to which preschool teachers partly believe that the children with disabilities have difficulties in their social interaction, this points to the importance of creating an encouraging environment and optimal conditions for the holistic development of each child's personality. Furthermore, the results show that it is important for preschool teachers to regularly inform parents about the noticed characteristics and disabilities of their child, and to regularly carry out individualized procedures and exercises with the children with disabilities, except when it comes to conducting workshops in order to engage and connect the children with disabilities with their peers without disabilities, which can be well planned and developed through mutual relations between individuals, teams, institutions and the wider social setting. In this context, a key feature of a 'competent system' is seen in its support for professionals to understand their responsibility in practice that responds to the educational needs of children and families in a constantly changing and evolving social context (Urban et al., 2012).

This research needs to be considered with some limitations, such as sample size, and it is important to understand the results taking them into account. From the foregoing, the necessity of caution in making conclusions arises and the results presented here should be interpreted as preliminary. Future research is important in this regard, as this study addresses relatively unexplored issues in our country, which may be an impetus for further research into the inclusive practice of early and preschool education.

\section{References}

[1] Akalin, S., Demir, Ş., Sucuoğlu, B., Bakkaloğlu, H. and İşcen, F. (2014). The needs of inclusive preschool teachers about inclusive practices. Eurasian Journal of Educational Research, vol. 54, pp. 39-60.

[2] Avramidis, E., Bayliss, P. and Burden, R. (2000). A survey into mainstream teachers' attitudes towards the inclusion of children with special educational needs in the ordinary school one local education authority. Educational Psychology, 20(2), pp.191-211. 


\section{LNAËUUCATION

[3] Bailey, D. B., McWilliam, R. A., Buysse, V. and Wesley, P. W. (1998). Inclusion in the the Context of Competing Values in Early Childhood Education. Early Childhood Research Quarterly, 13(1), pp. 27-47.

[4] Bricker, D. (1995). The challenge of inclusion. Journal of Early Intervention, 19(3), pp.179-194.

[5] Buysse, V., Wesley, P., Bryant, D. M. and Gardner, D. (1999). Quality of early childhood programs in inclusive and noninclusive settings. Exceptional Children,vol. 65, pp. 301-314.

[6] Colwell, M. J. and Lindsey, E. W. (2003). Teacher-Child Interactions and Preschool Children's Perceptions of Self and Peers. Early Child Development and Care, 173(2-3), pp. 249-258. Available: https://www.researchgate.net/publication/247499647_TeacherChild_Interactions_and_Preschool_Children\%27s_Perceptions_of_Self_and_Peers.

[7] Coombs-Richardson, R. and Mead, J. (2001). Supporting general educators' inclusive practices. Teacher Education and Special Education, 24(4), pp. 383-390.

[8] Crane-Mitchell, L. and Hedge, A. V. (2007). Beliefs and practices of in-service preschool teachers in inclusive settings: implications for personnel preparation. Journal of Early Childhood Teacher Education, vol. 28, pp. 353-366.

[9] Devarakonda, C. (2013). Diversity and Inclusion in Early Childhood. An Introduction. London: Sage.

[10] Division for Early Childhood Recommended Practices - DEC-RP (2014). Available: https://www.dec-sped.org/dec-recommended-practices.

[11] Eiserman, W. D., Shisler, L. and Healey, S. (1995). A community assessment of preschool providers' attitudes toward inclusion. Journal of Early Intervention, vol. 19, pp. 149-167.

[12] European Policy Cooperation (ET 2020 framework) - The strategic framework for European cooperation in education and training. Available: https://ec.europa.eu/education/policies/european-policy-cooperation/et2020framework_en

[13] Hadadian, A. and Hargrove, L. (2001). Child care perspectives on inclusion: do we have to go a long way to go? Infant-Toddler Intervention: The Transdisciplinary Journal, vol. 11, pp. 49-58.

[14] Heekin, S. and Mengel, P. (1997). NOVI prijatelji: kako pomoći djeci predškolske i mlađe školske dobi u razumijevanju i prihvaćanju individualnih razlika: priručnik za odgajatelje i učitelje. Zagreb: Mali profesor.

[15] Kudek Mirošević, J. and Jurčević Lozančić, A. (2014). Stavovi odgojitelja i učitelja o provedbi inkluzije u redovitim predškolskim ustanovama i osnovnim školama. Hrvatska revija za rehabilitacijska istraživanja, 50(2), pp.17-29.

[16] Lorenz, S. (2002). First steps in Inclusion. London: David Futton Publishers.

[17] Michelle, D. (2012). The social development of children with mild developmental disabilities in iclusive preschools. Vanderbilt: Vanderbilt University, Peabody College. 


\section{LNAËUUCATION \\ 27-29 March, 2020 \\ Oxford, United Kingdom}

[18] Mikas, D. and Roudi, B. (2012). Socijalizacija djece s teškoćama u razvoju u ustanovama predškolskog odgoja. Paediatria Croatica, 56(1), pp. 207-214. Available: https://docplayer.net/23932038-Socijalizacija-djece-s-teskocama-u-razvoju-u ustanovamapredskolskog- odgoja.html

[19] Ministarstvo znanosti i obrazovanja. Zakon o predškolskom odgoju i obrazovanju, Narodne novine, 10/97, 107/07, 94/13.

[20] Ministarstvo znanosti i obrazovanja (2016). Okvir za poticanje i prilagodbu iskustava učenja te vrednovanje postignuća djece i učenika s teškoćama. Nacionalni dokument, Republika Hrvatska.

[21] Odom, S. L. (2000). Preschool inclusion: What we know and where we go from here. Topics in Early Childhood Special Education, 20(1), pp. 20-27.

[22] Odom, S. L. (2002). Widening the cirkle: including cildren with disabilities in preschool programs. New York and London: Teachers College Press.

[23] Odom, S. L. and Diamond, K. E. (1998). Inclusion of Young Children with Special Needs In Early Childhood Education: The Research Base. Early Childhood Research Quarterly, 13(1), pp. 3-25.

[24] Rinaldi, C. (2006). In Dialogue with Reggio Emilia: listening, researching and learning. New York: Routledge.

[25] Sekulić-Majurec, A. (1997). Integracija kao pretpostavka uspješne socijalizacije djece i mladeži s teškoćama u razvoju: očekivanja, postignuća, perspektive. Društvena istraživanja, 6, 4/5 (30/31), pp. 537-550.

[26] Torstenson-Ed, T. (2007). Children's Life Paths Through Preschool and School: Letting youths talk about their own childhood - theoretical and methodological conclusions, Childhood, 14(1), pp. 47-66.

[27] Tot, D. (2013). Evaluations of Learners, Teachers and School Management Boards with Regard to the Indicators of Contemporary Teacher Competences. Croatian Journal of Education, 15(3), pp. 801-821.

[28] United Nations (2006). General Comment No. 7 (2005): Implementing Child Rights in Early Childhood. Committee on the Rights of the Child, Fortieth Session, Geneva, 1230 September 2005. United Nations: Geneva. Available: www2.ohchr.org/english/bodies/crc/docs/AdvanceVersions/GeneralComment7Rev1.pdf

[29] United Nations (2015). Transforming our World: The 2030 Agenda for Sustainable Development. New York: United Nations.

[30] Urban, M., Vandenbroeck, M., Van Laere, K., Lazzari, A. and Peeters, J. (2012). Towards Competent Systems in Early Childhood Education and Care. Implications for Policy and Practice. European Journal of Education, 47(4), pp. 508-526.

[31] Vandenbroeck, M., Coussée, F. and Bradt, L. (2010). The social and political construction of early childhood education. British Journal of Educational Studies, 58(2), pp. 139-153. 